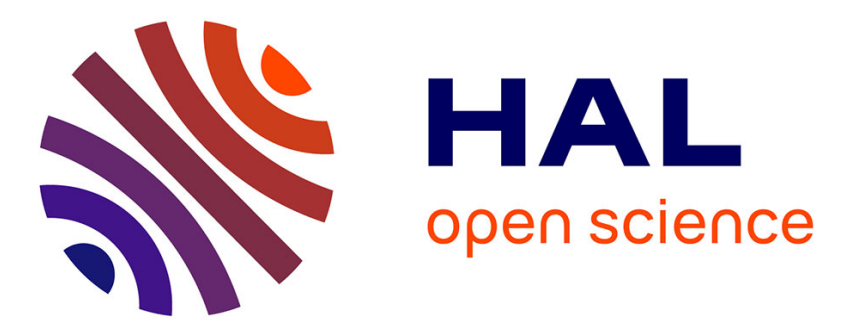

\title{
Behaviour of imidacloprid in fields. Toxicity for honey bees
}

\author{
J.M. Bonmatin, I. Moineau, R. Charvet, M.E. Colin, C. Fléché, E.R. Bengsch
}

\section{To cite this version:}

J.M. Bonmatin, I. Moineau, R. Charvet, M.E. Colin, C. Fléché, et al.. Behaviour of imidacloprid in fields. Toxicity for honey bees. E. Lichtfouse; J. Schwarzbauer; D. Robert. Environmental Chemistry. Green chemistry and pollutants in ecosystems, Springer, pp.483-494, 2005, 978-3-540-22860-8. 10.1007/3-540-26531-7_44. hal-00088509

\section{HAL Id: hal-00088509 https://hal.science/hal-00088509}

Submitted on 29 Sep 2021

HAL is a multi-disciplinary open access archive for the deposit and dissemination of scientific research documents, whether they are published or not. The documents may come from teaching and research institutions in France or abroad, or from public or private research centers.
L'archive ouverte pluridisciplinaire HAL, est destinée au dépôt et à la diffusion de documents scientifiques de niveau recherche, publiés ou non, émanant des établissements d'enseignement et de recherche français ou étrangers, des laboratoires publics ou privés. 


\title{
Behaviour of Imidacloprid in Fields. Toxicity for Honey Bees
}

\author{
J. M. Bonmatin · I. Moineau $\cdot$ R. Charvet $\cdot$ M. E. Colin $\cdot$ C. Fleche $\cdot$ E. R. Bengsch
}

\begin{abstract}
Following evidence for the intoxication of bees, the systemic insecticide imidacloprid was suspected from the mid nineties of having harmful effects. Recently, some studies have demonstrated that imidacloprid is toxic for the bees at sub-lethal doses. These doses are evaluated in the range between 1 and $20 \mathrm{mg} \mathrm{kg}^{-1}$, or less. It appeared thus necessary to study the fate of imidacloprid in the environment at such low levels. Thus, we developed methods for the determination of low amounts, in the $\mu \mathrm{g} \mathrm{kg}^{-1}$ range, of the insecticide imidacloprid in soils, plants and pollens using high pressure liquid chromatography - tandem mass spectrometry (LC/APCI/MS/MS). The extraction and separation methods were performed according to quality assurance criteria, good laboratory practices and the European Community's criteria applicable to banned substances (directive 96/23 EC). The linear concentration range of application was $1-50 \mu \mathrm{g} \mathrm{kg}^{-1}$ of imidacloprid, with a relative standard deviation of $2.9 \%$ at $1 \mu \mathrm{g} \mathrm{kg}^{-1}$. The limit of detection and quantification are respectively LOD $=0.1 \mu \mathrm{g} \mathrm{kg}^{-1}$ and $\mathrm{LOQ}=1 \mu \mathrm{g} \mathrm{kg}^{-1}$ and are suited to the sub-lethal dose range. This technique allows the unambiguous identification and quantification of imidacloprid. The results show the remanence of the insecticide in soils, its ascent into plants during flowering and its bioavailability in pollens.
\end{abstract}

Key words: imidacloprid, insecticide, Gaucho ${ }^{\circledR}$, analysis, soils, plants, pollens, bees

\section{1}

\section{Introduction}

Various insecticides to protect crops against insects have been used over the last 40 years. Most insecticides were applied by spraying in large quantities, thus inducing pollution of air, soils and waters. In the 1990s, new insecticides were sold and announced as being efficient. Their implementation allowed the reduction in use of large quantities of pesticides and thus, to reduce pollution. Gaucho ${ }^{\circledR}$ is one of these new insecticides often used as a seed-dressing and imidacloprid is its active compound.

Imidacloprid is a systemic chloro-nicotinyl insecticide (Placke and Weber 1993). This propriety allows pesticide to rise into the sap and its distribution in the plant. It is used for soils, seeds and foliar applications for the control of sucking insects, including rice hoppers, aphids, thrips, whiteflies, termites, turf insects, soil insects and some beetles. It is most commonly used on rice, cereal, maize, sunflowers, potatoes and vegetables. It is especially systemic when used as a seed or soil treatment (Nauen et al. 1998). The active chemical works by interfering with the transmission of stimuli in the insect's nervous system. Specifically, it causes a blockage in the nicotinergic neuronal pathway that is more abundant in insects than in warm-blooded animals, making the chemical much more toxic to insects than to warm-blooded animals. This 
Fig. 44.1.

Production of honey in west France. Note the decrease of after 1994, which could be explained partly by the use of the insecticide on sunflower. The vertical axis is graduated in $\%$ and $100 \%$ corresponds to the mean production between 1988 and 1994

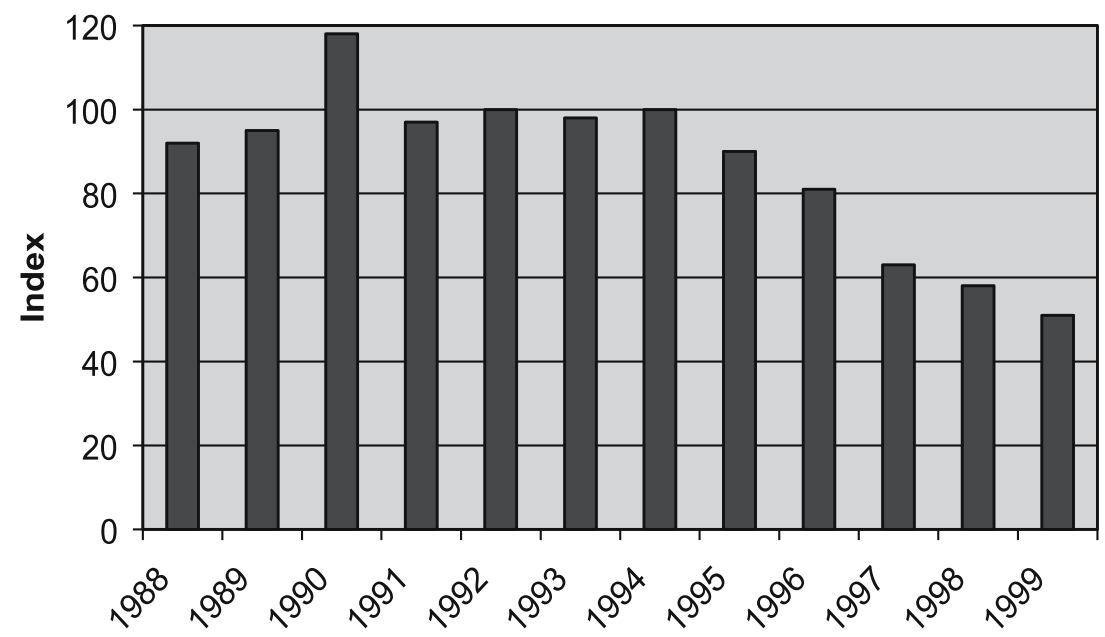

binding on the nicotinic acetylcholine receptor (nAChR) leads to the accumulation of the acetylcholine neurotransmitter, resulting in the paralysis and death of the insect (Okazawa et al. 1998).

The seed-dressing for sunflowers was launched on the French market in 1994 with the name of Gaucho ${ }^{\circledR}$. From 1995, beekeepers have observed the death of numerous bees and the decrease in honey production (Fig. 44.1). This problem has worsened with the increasing use of Gaucho ${ }^{\circledR}$ on sunflower and on maize. As a result, imidacloprid has been suspected as having harmful effects on honeybees in fields.

Imidacloprid exhibits a high oral toxicity to honeybees. The oral lethal dose $50 \%$ $\left(\mathrm{LD}_{50}\right)$ is observed between 49 and $102 \mathrm{ng}$ per bee (Nauen et al. 2001), 3.7 and $40.9 \mathrm{ng}$ per bee (Schmuck et al. 2001), $5 \mathrm{ng}$ per bee (Suchail et al. 2001) or 40 and $60 \mathrm{ng}$ per bee (Suchail et al. 2001). These values correspond to a lethal food concentration ranging between 0.1 and $1.6 \mathrm{mg} \mathrm{kg}^{-1}$ (Schmuck et al. 2001). The contact $\mathrm{LD}_{50}$ is about $24 \mathrm{ng} /$ bee at 24 and $48 \mathrm{~h}$ (Suchail et al. 2001). The sub-lethal effect of imidacloprid on bees has not been investigated until recently. New studies have shown that the crucial functions of bees such as foraging are affected by sub-lethal doses of imidacloprid in the range from 1 to $20 \mu \mathrm{g} \mathrm{kg}^{-1}$ and from 0.1 to $2 \mathrm{ng} / \mathrm{bee}$ (Pham-Delegue and Cluzeau 1999; Colin and Bonmatin 2000). A dose of o.1 ng per bee can also induce a decrease of habituation (Guez et al. 2001). Today, the action of imidacloprid on bees is not yet fully understood. There are at least two levels of toxicity, one centred at about $5 \mathrm{ng} /$ bee and the other one at around $40 \mathrm{ng} /$ bee. Moreover, imidacloprid and its metabolites would still be very toxic at much lower doses due to chronic intoxication. Briefly, studies converge and show a complex mechanism with an important toxicity at doses of imidacloprid in the $\mu \mathrm{g} \mathrm{kg}^{-1}$ range, and even for lower amounts (Colin and Bonmatin 2000; Colin 2001; Guez et al. 2001; Belzunces 2001).

Nevertheless, data from Bayer AG indicated the absence of imidacloprid and its metabolite residues in the flowering of sunflowers raised from Gaucho ${ }^{\circledR}$ dressed seeds. This resulted from a sharp decrease of the imidacloprid content during the growth of treated plants. However, this data came from analysis using high performance liquid chromatography coupled with UV detection (HPLC/UV), which only allows quantification from $20-50 \mu \mathrm{g} \mathrm{kg}^{-1}$ (Placke and Weber 1993).

Based on the fact that harmful effects on bees appear in the $\mu \mathrm{g} \mathrm{kg}^{-1}$ concentration range, a more sensitive methodology was clearly needed to precisely determine the 
insecticide content of flowers and pollens. Thus, new studies were launched in France by government agencies from 1998 (AFSSA, CNRS, INRA). One of the aims was to develop modern analytical methods allowing a limit of quantification (LOQ) near $1 \mu \mathrm{g} \mathrm{kg}^{-1}$. For a comprehensive approach of the imidacloprid behaviour in fields, methods had to be efficient for soils, plants, flowers and pollens from field samplings.

Several methods have been reported for the analysis of imidacloprid. Although imidacloprid residues can be analysed by derivatization and gas chromatography methods (Macdonald and Meyer 1998; Uroz et al. 2001), HPLC appears to be a good alternative because of the thermolability and polarity of imidacloprid (Baskaran 1997; Yih-Fen and Powley 2000; Pous et al. 2001). HPLC gave sensitive results for imidacloprid in groundwater (Martinez-Galera et al. 1998), but the limit of detection (LOD) had to be lowered for the present study. Here, we developed analysis by high performance liquid chromatography coupled with mass spectrometry in tandem (HPLC/MS/MS) to detect and quantify imidacloprid in soils, plants, flowers and pollens with a LOD of $0.1 \mu \mathrm{g} \mathrm{kg}^{-1}$ and a LOQ of $1 \mu \mathrm{g} \mathrm{kg}^{-1}$ (Bonmatin et al. 2000a,c; Bonmatin et al. 2001).

\section{2 \\ Experimental}

\subsection{1 \\ Samples and Extraction}

Soils, plants and pollens, were sampled throughout France and were analysed to follow the fate of imidacloprid in the environment. The chemical composition of soils, plants and pollens is very heterogeneous. Each material contains organic compounds which can induce perturbations for the analysis. Thus, efficient extraction was needed to detect imidacloprid with a very low limit of detection. That is why three specific extraction methods were applied. Supplementary samples of soils, plants and pollens, which were totally free of imidacloprid, were spiked with known amounts of imidacloprid for calibration and assessment of the quality of our experiments. To identify the presence of imidacloprid, the treated samples were also compared with organically-farmed samples. The extraction schemes are shown for soils, plants and pollens in Fig. 44.2.

\subsection{2}

\section{Analysis by Liquid Chromatography-Mass Spectrometry}

Although the extraction steps are efficient and selective, it is necessary to perform a separation by high performance liquid chromatography. Imidacloprid is thermo-labile, thus HPLC allows direct injection of the extract, whereas gas chromatography (GC) requires derivatization. The detection by mass spectrometry coupled to LC allows clear identification of the parent ion at $m / z=256$, a very high specificity using two or more ions products $(m / z=209$ and $m / z=175)$, and a very low limit of detection as detailed in the next section. 


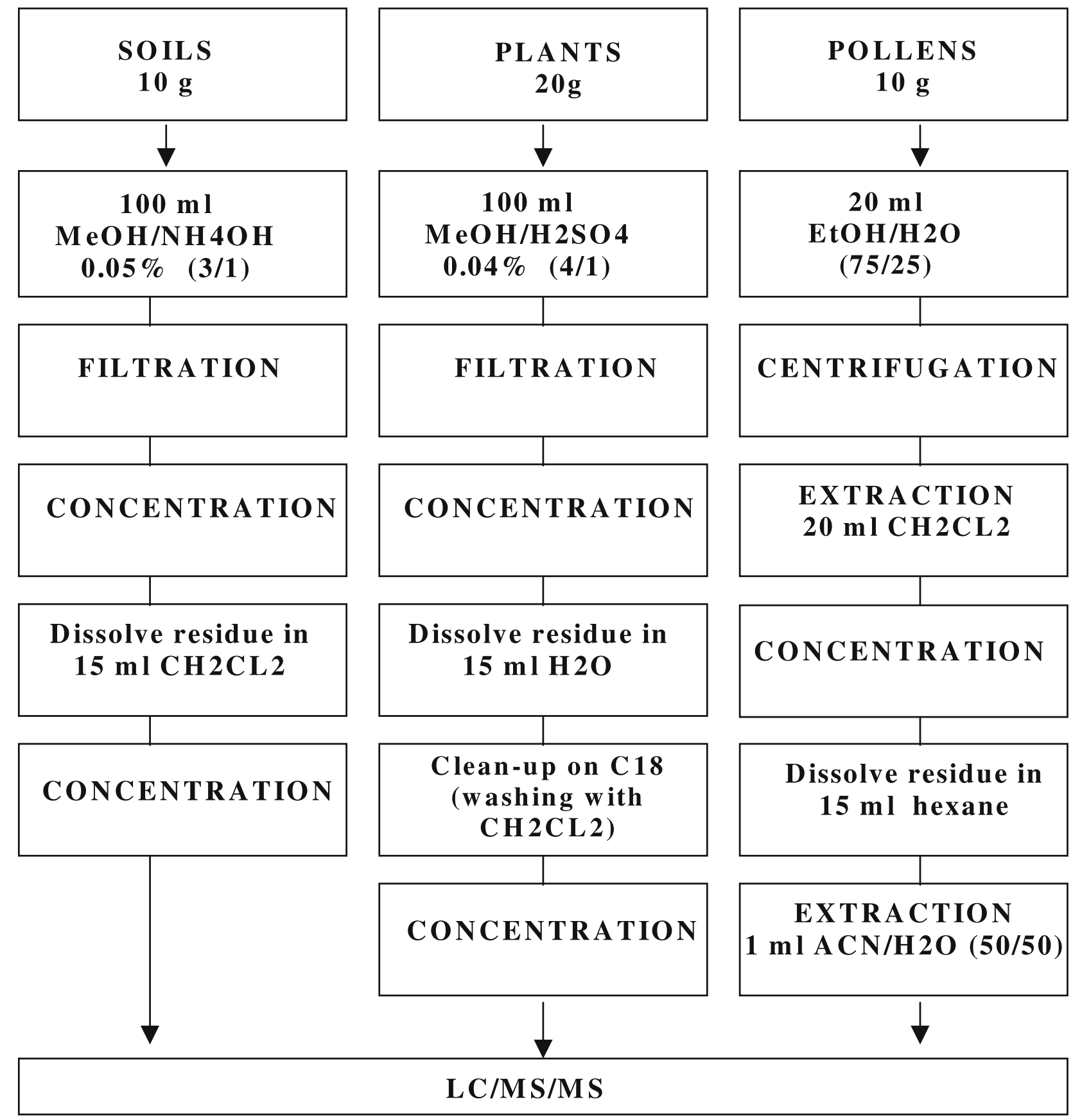

Fig. 44.2. Extraction schemes applied to soils, plants and pollens prior the separation and detection processes. Schemes were suited to obtain high recovery levels of imidacloprid at the level of the limit of quantification $\left(1 \mu \mathrm{g} \mathrm{kg}{ }^{-1}\right)$

Antipyrine was systematically used as an external standard between 10 injections of unknown samples. Unknown samples were also injected between series of standards and quality control samples. The retention time was constant with a deviation never exceeding $2.5 \%$. The retention time was typically $2.4 \mathrm{~min}$ for the plants and $2.8 \mathrm{~min}$ for the pollen and soils samples depending on the chosen chromatographic flow. Calibration graphs were plotted for six standard solutions between 0.5 and $20 \mu \mathrm{g} \mathrm{kg}^{-1}$ of imidacloprid added in extracted materials (blanks). For each calibration point, three injections into the liquid chromatograph were performed. Linearity was found in the range between 0.5 and $20 \mu \mathrm{g} \mathrm{kg}^{-1}$. The correlation coefficients were better than 0.99. 
Fig. 44.3.

Scheme of the selected fragmentations and the mass spectra corresponding to the product ions of imidacloprid

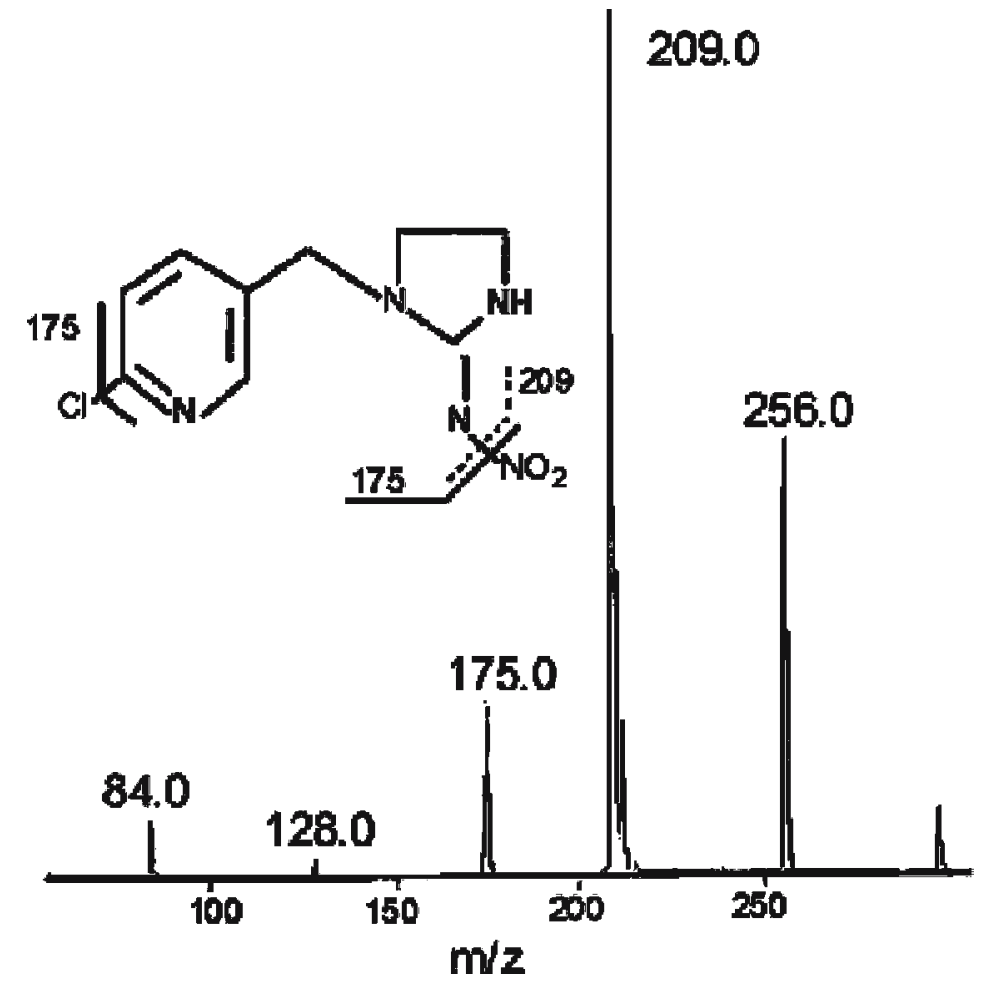

The specificity was performed by following two fragmentations of imidacloprid. The first fragment at $m / z=209$ is due to the loss of $\mathrm{NO}_{2}$. The second fragment at $\mathrm{m} /$ $z=175$ is due to the losses of both $\mathrm{NO}_{2}$ and $\mathrm{Cl}$ (Fig. 44.3). The chromatograms of product ions are clearly defined and are specific for imidacloprid. From multiple reaction monitoring (MRM) experiments, the ratio of the two product ion signals $(175 / 209)$ gives an averaged value near 0.4. The latter value comes from the analysis of standards. Such an average value differs slightly depending on the starting material (soils, plants, pollens). However, when performing analysis of unknown samples, it did not vary by more than $20 \%$, thus satisfying the corresponding quality criteria. Additionally, the ratio of ${ }^{35} \mathrm{Cl} /{ }^{37} \mathrm{Cl}$ imidacloprid signals was checked as a supplementary criteria of specificity.

The limit of detection was determined according to the signal of the less intense product ion. This limit was $0.1 \mu \mathrm{g} \mathrm{kg}^{-1}$ for soils and plants and $0.3 \mu \mathrm{g} \mathrm{kg}^{-1}$ for pollens. The limit of quantification was $1 \mu \mathrm{g} \mathrm{kg}^{-1}$ for each material type, with a $\mathrm{S} / \mathrm{N}=10$, the latter being averaged from 10 injections. Reproducibility was tested six times for three concentrations of imidacloprid $\left(1,10,18 \mu \mathrm{g} \mathrm{kg}^{-1}\right)$. The relative standard deviation values were lower than $18 \%$ for the plants and lower than $15 \%$ for pollens and soils. These values are in accordance with the quality criteria. The recovering rates (i.e. quantified quantity/theoretic quantity) are (i) in the $85-86 \%$ range for soils, (ii) in the $78-82 \%$ range for plants and (iii) in the $78-85 \%$ range for pollens. Note that relative concentrations of imidacloprid in the present paper were not recalculated to take account of the recovering rates, so these concentrations can be considered as being minimised by near $20 \%$. As a matter of fact, the method respects the criteria (retention time, ratio between the products ions, signal-to-noise ratio...) of the directive 96/23 EC which is designed for banned substances. It is thus not surprising that manufacturers including Bayer AG, nowadays adopt such methods for a better characterisation of their products (Yih-Fen and Powley 2000; Schmuck et al. 2001). 


\section{3}

\section{Results and Discussion}

\subsection{1}

\section{Soil Analysis}

French soils from numerous areas with varying climates, soil compositions and rain exposures were sampled. This approach gives our results a statistical dimension, allowing a general extrapolation in France (see Fig. 44.4). Among 74 samples of soils, 7 came from organic farming areas and did not reveal any signal of imidacloprid. These organically-farmed samples can be considered as control samples and demonstrate that the sampling procedure was performed without any external contamination. A total of 67 unknown samples were analysed. They are classified according to their imidacloprid content in Fig. 44.4 and we observed that 62 samples (91\%) contain imidacloprid unambiguously (LOD of $0.1 \mu \mathrm{g} \mathrm{kg}^{-1}$ ). In $65 \%$ of the cases, imidacloprid was quantified at more than $1 \mu \mathrm{g} \mathrm{kg}^{-1}$. Interestingly, only 10 samples came from areas where seeds were treated the year of sampling. Such a difference (between $15 \%$ of treated area and 91\% of positive soils) is not surprising and originates clearly from the long lifetime of imidacloprid in soils as outlined below.

To study the situation of areas with treated seed at the year of sampling, 10 soils were sampled after the cultivation of treated plants (seed treatment). Here, the plants were maize, wheat and barley. Among these 10 soils, 9 contained imidacloprid between 2 and $22 \mu \mathrm{g} \mathrm{kg}^{-1}$ with an average value of $12 \mu \mathrm{g} \mathrm{kg}^{-1}$. Only 1 sample contained a concentration lower than $1 \mu \mathrm{g} \mathrm{kg}^{-1}$. Thus, if the sampling is performed in the year of treatment, imidacloprid is always present in the soils and easily detectable after cultivation. For comparison, the amount of imidacloprid in soils can reach several hundred of $\mu \mathrm{g} \mathrm{kg}^{-1}$ during the cultivation, depending on the passed time between sowing and sampling.

Soils were also analysed when they were exposed to imidacloprid one or two years before the sampling year. Although 11 soils were not exposed to imidacloprid during the two years preceding sampling, 7 soils contained imidacloprid between 0.1 (LOD) and $1 \mu \mathrm{g} \mathrm{kg}^{-1}$ (LOQ) and one sample contained $1.5 \mu \mathrm{g} \mathrm{kg}^{-1}$. Subsequently, we considered soils for which no treated plants were cultivated the year of sampling ( $n$ ) but which had received treated seeds one or two years before ( $n-1$ and/or $n-2)$. A set of 33 samples corresponds to such cases. Imidacloprid is present in $97 \%$ of these soils.

Fig. 44.4.

Sampled soils (\%) as a function of the relative concentration of imidacloprid. Note that only $15 \%$ of these soils came from areas where seeds were treated

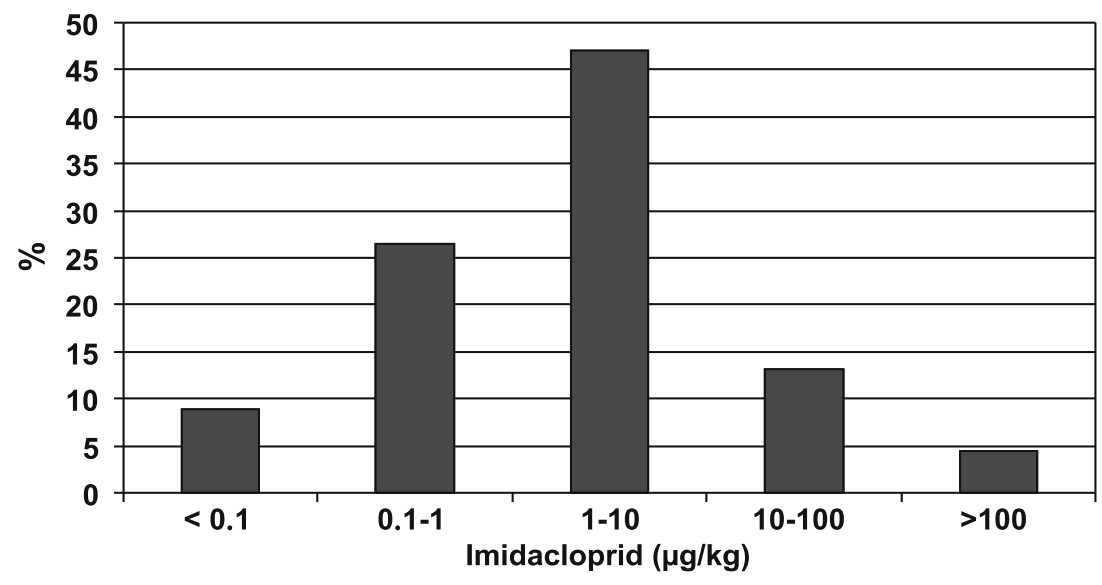


Moreover, its concentration ranges from 1.2 to $22 \mu \mathrm{g} \mathrm{kg}^{-1}$ in $78 \%$ of the samples and the mean value is $6 \mu \mathrm{g} \mathrm{kg}^{-1}$ in untreated soils (year $n$ ) which received treated seeds one year before sampling $(n-1)$. The mean value reaches $8 \mu \mathrm{g} \mathrm{kg}^{-1}$ in untreated soils which received treated seeds at years $n-1$ and $n-2$. This shows that a slight accumulation phenomenon in soils cannot be excluded.

Our data illustrates and confirms the strong retention of imidacloprid in soils. Note that the half life of imidacloprid in soils was already characterised from DT50 $=188$ to $249 \mathrm{~d}$ by laboratory experiments (Belzunces anf Tasei 1997) while the DT50 of metabolites are still unknown.

\subsection{2}

\section{Sunflower and Maize}

A first set of 17 samples contained mature sunflowers coming from organically-farmed crops. These samples were analysed and no trace of imidacloprid was detected. Thus, these samples can be considered as control samples and demonstrate again that there was no external contamination during sampling.

Concerning untreated plants, sunflowers appear to be particularly capable of recovering the residual imidacloprid still present in soils from previous cultivation. Actually, with an average value of imidacloprid of about $6 \mu \mathrm{g} \mathrm{kg}^{-1}$ in soils at year $n+1$, untreated sunflowers recover an average content of $1-2 \mu \mathrm{g} \mathrm{kg}^{-1}$ in flowering capitules. Imidacloprid is still detectable ( $\mathrm{LOD}=0.1 \mu \mathrm{g} \mathrm{kg}^{-1}$ ) in untreated sunflowers even after two years of consecutive treated cultivation.

A second set of samples came from treated Gaucho ${ }^{\circledR}$ areas. The authorised dose for a Gaucho ${ }^{\circledR}$ treatment was $0.7 \mathrm{mg} \mathrm{seed}^{-1}$ for sunflowers. Despite the fact that the concentration of imidacloprid in growing plants sharply decreases with the time due to the increasing of biomass, a new phenomenon in sunflower capitulums was observed from all areas and for all studied sunflower varieties. Note that the part of sunflower named capitule is defined as a thick head of flowers on a very short axis, as a clover top, or a dandelion; a composite flower. Actually, from the appearance of the capitulums (about 40-50 d after sowing), the concentration of imidacloprid stops decreasing and, on the contrary, starts to increase. This increase of the imidacloprid concentration in capitulums is observed for 5 varieties of sunflowers. It is illustrated in Fig. 44.5 for one

Fig. 44.5.

Relative concentration $(\mu \mathrm{g} \mathrm{kg}-1)$ of imidacloprid in sunflowers capitutules as a function of the stages of growth. Codification of stages is defined according to Lancashire and Bleiholder 1991. Data are shown for 3 doses of seed-dressing: $N, 1.5 \mathrm{~N}$ and $2 N$ ( $N$ : authorised dose on sunflowers). The sunflower variety is Rigasol. From the capitule formation (stage 59), the ascent of imidacloprid concentration is observed for the 3 doses of seed-dressing

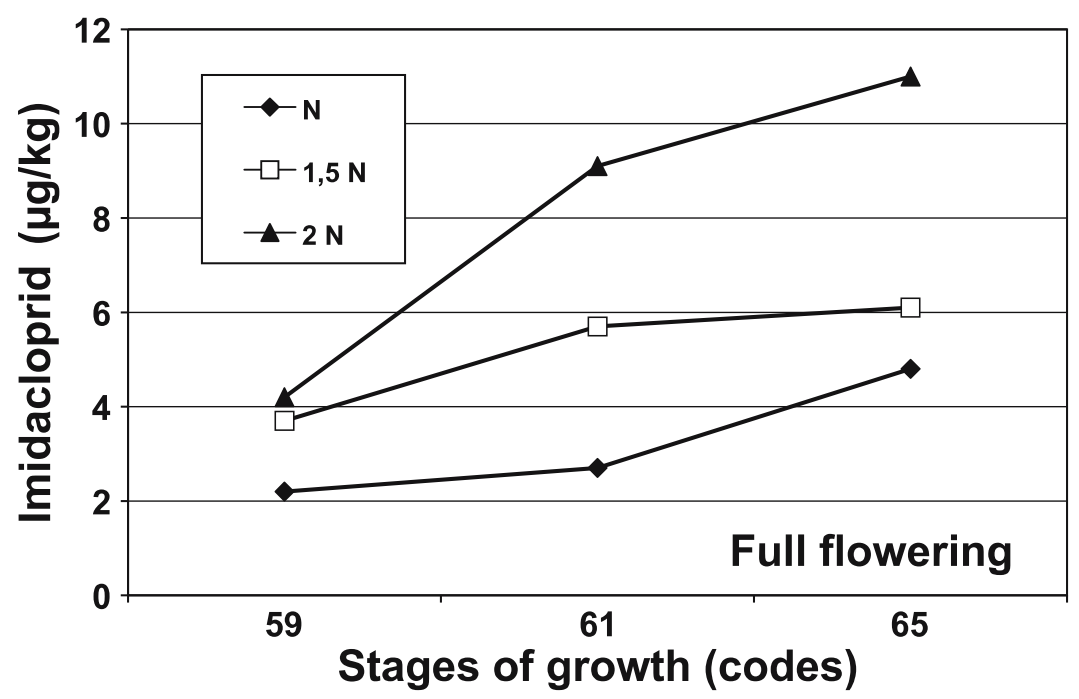


variety, at 3 stages $(59,61,65)$ of growth during the capitulum formation and for 3 doses of dressing: the authorised dose $N, 1.5 N$ and $2 N$. First, whatever the dose, the imidacloprid content significantly increases during flowering. Secondly, the concentration of imidacloprid in the capitulums, especially at full flowering, depends on the dose used for the seed-dressing, the contamination being greater when the dose is increased.

With regards to the behaviour of sunflowers depending on the variety, five varieties were treated with the authorised dose $(N)$ and cultivated in the same area. The varieties were Pharaon, Rigasol, DK3790, Albena and Natil. Some varieties are rarely used in France (ex: Pharaon), while others are quite widely cultivated (ex: DK3790). Clearly, the decrease of imidacloprid quantities in sunflowers then followed by its ascent in the capitulum during flowering, were confirmed for all varieties of sunflowers, as seen in Fig. 44.6. The graph shows that values of imidacloprid in the capitulum during flowering, range from $2.5 \mu \mathrm{g} \mathrm{kg}-1$ (Pharaon) to $9 \mu \mathrm{g} \mathrm{kg}^{-1}$ (Albena). Finally, the ascent of imidacloprid into the capitulums is a general phenomenon, leading to a final amount in the range of 1 to $10 \mu \mathrm{g} \mathrm{kg}^{-1}$ of the toxin in the flowering heads accessible to bees.

This new phenomenon is demonstrated in all sampled areas, varieties of sunflowers and doses of seed-dressing. Obviously, the ascent of imidacloprid during flowering is more pronounced when the doses of the seed dressing are high. With the authorised dose, the mean content of imidacloprid in sunflowers capitulums is $8 \mu \mathrm{g} \mathrm{kg}^{-1}$ during flowering. These results do not conflict with those from the manufacturer, which reported the absence of imidacloprid in flowers, since the limit of detection was unfortunately set at $20 \mu \mathrm{g} \mathrm{kg}^{-1}$ using HPLC/UV (Placke and Weber 1993). Our results are consistent with data from ${ }^{14} \mathrm{C}$ imidacloprid quantification in the head part of sunflowers. Here imidacloprid residues were found in the range from 5 to $30 \mu \mathrm{g} \mathrm{kg}^{-1}$ (Laurent

Fig. 44.6.

Relative concentration $\left(\mu \mathrm{gg}^{-1}\right)$ of imidacloprid in sunflower capitules as a function of the stages of growth (Lancashire and Bleiholder 1991). Data are shown for 5 treated sunflowers varieties. Note that from stage 59, imidacloprid level increases until the full flowering (stage 65) for all varieties

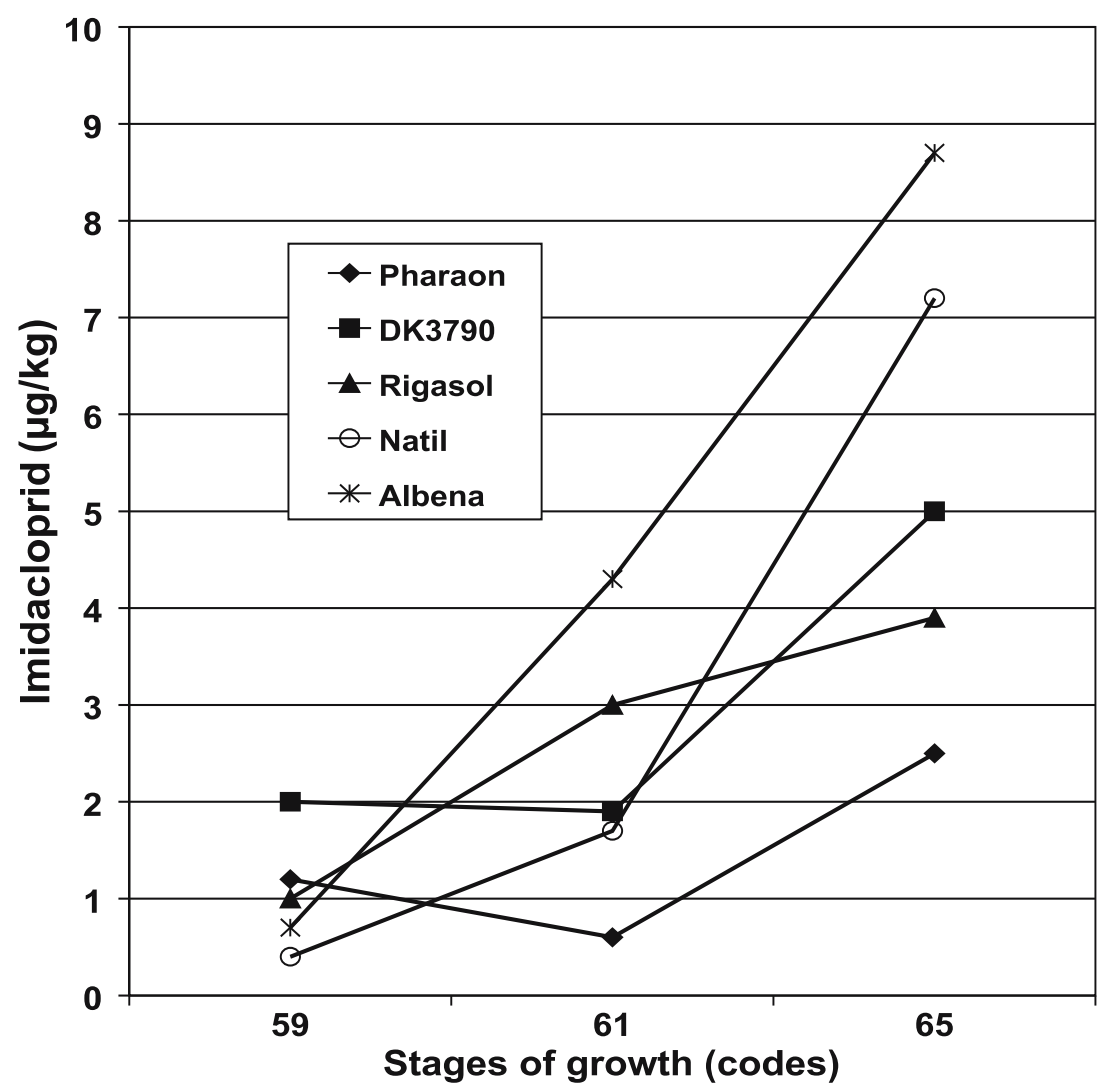


and Scalla 2000). Note that ${ }^{14} \mathrm{C}$ methods are suited to laboratory or semi-laboratory investigations and cannot be used for investigations of a global and statistical description of the behaviour in fields.

\subsection{3 \\ Pollens}

The study of pollens was performed on a set of sixty four sunflower pollen samples. A first set of eleven pollens came from organic farming crops and do not reveal the presence of imidacloprid. A second set of twenty nine pollens came from untreated Gaucho ${ }^{\circledR}$ crops in the year of sampling $(n)$. Two of them showed a clearly positive result $\left(\mathrm{LOD}=0.3 \mu \mathrm{g} \mathrm{kg}^{-1}\right.$ ) but concentrations were less than the $\mathrm{LOQ}=1 \mu \mathrm{g} \mathrm{kg}^{-1}$. As a matter of fact, the latter two pollens came from areas where Gaucho ${ }^{\circledR}$ crops were sowed the year before sampling $(n-1)$. This demonstrates that the persistence of imidacloprid in soils can sometimes lead to its recovery by untreated sunflowers sowed one year later. Thus, the toxin can reach the highest parts of the plant and can contaminate pollens. A third set of 24 samples of pollens from treated sunflowers were analysed. In only $17 \%$ of pollens, imidacloprid was not detected ( $\left.\mathrm{LOD}=0.3 \mu \mathrm{g} \mathrm{kg}^{-1}\right) .25 \%$ of samples were positive with the amount of imidacloprid not exceeding $1 \mu \mathrm{g} \mathrm{kg}^{-1}$. Other pollens $(58 \%)$ contained imidacloprid at concentrations from 1 to $11 \mu \mathrm{g} \mathrm{kg}^{-1}$ and the mean value is centred at $3 \mu \mathrm{g} \mathrm{kg}^{-1}$.

The mean value found in pollens from treated sunflowers corresponds to the quantity of imidacloprid inducing sub-lethal effects on foraging bees (Colin and Bonmatin 2000; Colin 2001). This means that the toxic is bioavailable during flowering and that foraging bees are first exposed to such doses by contact. Moreover, this means that pollens represent a way for the toxin to contaminate the beehive. Since pollens are stocked in the beehive and constitute a main source of nutriments (oral exposure). Our results on pollens are in agreement with the ${ }^{14} \mathrm{C}$ experiments from which the toxic content (imidacloprid and metabolites) was estimated at $13 \mu \mathrm{g} \mathrm{kg}{ }^{-1}$. Furthermore, our results are confirmed by Bayer AG (Schmuck et al. 2001). These authors recently used a similar LC/MS/MS technique to the one we developed, but with a 15 -fold higher limit of detection at $1.5 \mu \mathrm{g} \mathrm{kg}^{-1}$. They reported $3.3 \mu \mathrm{g} \mathrm{kg}^{-1}$ in pollens and $1.9 \mu \mathrm{g} \mathrm{kg}^{-1}$ in nectars.

\section{4}

\section{Conclusion}

We developed three extraction schemes followed by LC/MS/MS method to detect imidacloprid from field samples. These analytical methods are designed to reveal (limit of detection of $0.1 \mu \mathrm{g} \mathrm{kg}^{-1}$ ) and quantify (limit of quantification of $1 \mu \mathrm{g} \mathrm{kg}^{-1}$ ) very low concentrations of imidacloprid in soils, plants and pollens. To date, these methods are the most sensitive methods available to analyse such materials according to good laboratory practice and quality criteria from the directive 96/23/EC (Bonmatin 2002).

The long persistence, after one and two years, of imidacloprid in soils has been demonstrated in this study. Retention of imidacloprid in soils, coupled with the abil- 
ity of sunflowers to recover the insecticide during the next cultivation, clearly explains the presence of imidacloprid in untreated plants. This situation is also observed for maize and several weeds or adventitious plants (plants which grow in fields but which have not been sown). For untreated wheat, rape and barley, imidacloprid is also recovered to a lesser extent from contaminated soils (Bonmatin et al. 200ob).

Seed treatment using imidacloprid protects plants against insects and is supposed to vanish before the arrival of pollinator insects. However, a new phenomenon has been demonstrated. We have shown that the relative amount of imidacloprid reaches a minimum, then increases in sunflowers from the time of the capitulum formation. As a consequence, relatively high levels are observed during flowering in the flowering heads. At this time, the capitulums of sunflowers contain a mean value of $8 \mu \mathrm{g} \mathrm{kg}-1$ of imidacloprid. Another study on maize indicates a similar situation. The ascent of imidacloprid during flowering appears to be general behaviour, due to both enhanced metabolism and the strong mobilisation of resources for plants producing large amounts of grains such as sunflowers and maize.

Our data reveals the presence of imidacloprid in pollens with average values of $3 \mu \mathrm{gg}^{-1}$ (sunflowers and maize). Thus, imidacloprid appears to be bioavailable for bees in fields, in a range of concentrations corresponding to that of sub-lethal effects on bees and especially concerning the foraging activity (Colin and Bonmatin 2000; Colin 2001). This risk situation with respect to sunflowers and maize is worsened when considering (i) the additional toxic action of several imidacloprid metabolites (Nauen et al. 1998; Oliveira et al. 2000) as well as (ii) the very low concentrations inducing chronic mortality of bees which are in the $0.1-1 \mu \mathrm{g} \mathrm{kg}^{-1}$ range (Suchail et al. 2001; Belzunces 2001).

The commercialisation and the use of Gaucho ${ }^{\circledR}$ on sunflowers have been suspended in France since 1999 (J.O.R.F. 1999).

\section{Acknowledgements}

This expertise was carried out for the French Ministries of Agriculture and Environment with the financial support of the EC 1221/97 program. The authors would like to thank Dr Sophie Lecoublet and Valérie Charrier for their participation in this research.

\section{References}

Baskaran K, Kookana RS, Naidu RJ (1997) Determination of the pesticide imidacloprid in water and soil using high-performance liquid chromatography. J Chromatogr 787:271-275

Belzunces LP (2001) In: Rapport d'étude 2000-2001 au Ministère de l'Agriculture et de la Pêche, VIème Programme Communautaire pour l'Apiculture, Projet 2106

Belzunces LP, Tasei J-N (1997) Impacts sur les dépeuplements de colonies d'abeilles et sur les miellées. In: Rapport au Ministère de l'agriculture sur les effets des traitements de semences de tournesol au Gaucho ${ }^{\circledR}$ (imidacoprid)

Bonmatin J-M (2002) Insecticides et pollinisateurs: une dérive de la chimie? Science 2:42-46

Bonmatin J-M, Moineau I, Colin M-E, Bengsch ER, Lecoublet $S$ and Fleché C (200oa) Effets des produits phytosanitaires sur les abeilles. Programmes 1999-2000 AFSSA-CNRS-INRA. In: Rapport de résultats $\mathrm{N}^{\circ} 3$ au Ministère de l'Agriculture et de la Pêche 
Bonmatin J-M, Moineau I, Colin M-E, Fleché C, Bengsch ER (20oob) Insecticide imidacloprid: availability in soils and plants, toxicity and risk for honeybees. EPRW 2000. Pesticides in Food and drink. p 134

Bonmatin J-M, Moineau I, Colin M-E, Fléché C, Bengsch ER (2000c) L'insecticide imidaclopride: Biodisponibilité dans les sols et les plantes, toxicité et risque pour les abeilles. Revue Française d'Apiculture 609:360-361

Bonmatin J-M, Moineau I, Lecoublet S, Colin M-E, Fléché C, Bengsch ER (2001) Neurotoxiques systémiques: biodisponibilité, toxicité et risque pour les insectes pollinisateurs - le cas de l'imidaclopride-, Produits Phytosanitaires. Eds. Presse Universitaires, Reims, France, pp 175-181

Colin M-E (2001) Influence des insecticides systémiques sur l'apprentissage spatio-temporel de l'abeille, Public conférence INRA/UAPV, 22 May 2001, Avignon, France

Colin M-E, Bonmatin J-M (2000) Effets de très faibles concentrations d'imidaclopride et dérivés sur le butinage des abeilles en conditions semi-contrôlées. In: Rapport au Ministère de l'agriculture et de la pêche

Directive 96/23/CE (1996) (Revision of commission decision 93/256/EC) Commission decision laying down analytical methods to be used for detecting certain substances and residues there of in live animals and animal products according to Council Directive 96/23/EC

Guez D, Suchail S, Gauthier M, Maleszka R, Belzunces L (2001) Contrasting effects of imidacloprid on habituation in 7 and $8 \mathrm{~d}$ old honeybees (Apis mellifera). Neurobiol Learning Memory 76:183-191

Journal Officiel de la République Française (1999) Avis aux détenteurs et aux utilisateurs de semences de tournesol. Ministère de l'agriculture et de la pêche, 14 février 1999, p 2413

Lancashire PD, Bleiholder H (1991) A uniform decimal code for growth stages of crops and weeds. Ann Appl Biol 119:561-601

Laurent F, Scalla R (2000) Transport et métabolisme de l'imidaclopride chez le tournesol. zème Programme Communautaire pour l'apiculture. Année 1999-2000. In: Rapport au Ministère de l'Agriculture et de la Pêche

MacDonald L, Meyer TJ (1998) Determination of imidacloprid and triadimefon in white pine by gas chromatography/mass spectrometry. Agric Food Chem 46:3133-3138

Martinez-Galera M, Garrido-Frenich A, Martinez-Vidal JL, Parrilla-Vasquez P (1998) Resolution of imidacloprid pesticide and its metabolite 6-chloronicotinic acid using cross-sections of spectrochromatograms obtained by high-performance liquid chromatography with diode-array detection. J Chromatogr A 799:149-154

Nauen R, Hungenberg H, Tollo B, Tietjen K, Elbert A (1998) Antifeedant effect, biological efficacy and high affinity binding of imidacloprid to acetylcholine receptors in Myzus persicae and Myzus nicotianae. Pest Managem Sci 53:133-140

Nauen R, Ebbinghaus-Kintscher U, Schmuck R (2001) Toxicity and nicotinic acetylcholine receptor interaction of imidacloprid and its metabolites in Apis mellifera (Hymenoptera: Apidae). Pest Managem Sci 57:577-586

Okazawa A, Akamatsu M, Ohoka A, Nishiwaki H, Cho WJ, Nakagawa N, Ueno T (1998) Prediction of the binding mode of imidacloprid and related compounds to house-fly head acetylcholine receptors using three-dimensional QSAR analysis. Pestic Sci 54:134-144

Oliveira RS, Koskinen WC, Werdin NR, Yen PY (2000) Sorption of imidacloprid and its metabolites on tropical soils. J Environ Sci Health B35:39-49

Pham-Delegue MH, Cluzeau S (1999) Effets des produits phytosanitaires sur l'abeille; incidence du traitement des semences de tournesol par Gaucho sur les disparitions de butineuses. Rapport final de synthèse au Ministère de l'Agriculture et de la Pêche

Placke FJ, Weber E (1993) Method for determination of imidacloprid residues in plant materials. Pflanzenschutz-Nachrichten Bayer 46/1993, p 2

Pous X, Ruiz M, Pico Y, Font G (2001) Determination of imidacloprid, metalaxyl, myclobutanil, propham, and thiabendazole in fruits and vegetables by liquid chromatography-atmospheric pressure chemical ionization-mass spectrometry. Fresenius J Anal Chem 371:182-189

Schmuck R, Schöning R, Stork A, Schramel O (2001) Risk posed to honeybees (Apis mellifera L., Hymenoptera) by an imidacloprid seed dressing of sunflowers. Pest Managem Sci 57:225-238 
Suchail S (2001) Etude pharmacocinétique et pharmacodynamique de la létalité induite par l'imidaclopride et ses métabolites chez l'abeille domestique (Apis mellifera L.). Thèse, Université Claude Bernard-Lyon I, $\mathrm{N}^{\circ} 04-2001$

Suchail S, Guez D, Belzunces LP (2001) Discrepancy between acute and chronic toxicity induced by imidacloprid and its metabolites in Apis mellifera. Environ Toxicol Chem 20:2482-2486

Uroz FJ, Arrebola FJ, Egea-Gonzales FJ, Martinez-Vidal JL (2001) Monitoring of 6-chloronicotinic acid in human urine by gas chromatography-tandem mass spectrometry as indicator of exposure to the pesticide imidacloprid. Analyst 126:1355-1358

Yih-Fen M, Powley CR (2000) LC/MS/MS: The method of choice in residue analysis. EPRW 2000. Pesticides in Food and Drink, p 102 